\title{
The Impact of Snail Trails and Cracks to Energy Output of Photovoltaic Modules At Lotas Off-Grid PV System
}

\author{
Rusman Sinaga ${ }^{1}$, Julius A. Tanesab ${ }^{2}$, Marthen Dangu Elu Beily ${ }^{3}$ \\ \{rusman_ipb99@apps.ipb.ac.id ${ }^{1}$,julius_halan@pnk.ac.id² marthen.baily@yahoo.co.id ${ }^{3}$ \} \\ Electrical Engineering Department, State Polytechnic of Kupang, \\ Jalan Adisucipto Kupang, Indonesia ${ }^{123}$
}

\begin{abstract}
This paper analyzes the impact of the snail trails and cracks phenomena in 200 Wp photovoltaic (PV) modules to energy output after five years of operation. Data collection was carried out through string voltage measurement, visual inspection, and Real Operating Conditions (ROC) test for permanently degraded PV especially the type of snail trail and crack degradation conducted at the Lotas Off-Grid PV System, South Central Timor Indonesia. For this paper, we applied quantitative methods to analyze data. The result shows that the permanent degradation caused by the snail trail will experience a maximum power decrease of 67 Watt per $\mathrm{m}^{2}$, while permanent degradation caused by crack will experience a power decrease of $551 \mathrm{Watt} / \mathrm{m}^{2}$.
\end{abstract}

Kewords: PV module, snail trail, cracks, energy, production

\section{Introduction}

The use of solar energy for electricity production sharply increased due to the ongoing $\mathrm{CO}_{2}$ emission reduction policies and significant technical developments from Photovoltaic (PV) technology [1], and solar modules are one of the best choices for rural electricity providing it is difficult to be reached by the Indonesian state electricity company (PLN) [2],[3]. At present solar modules are considered a reliable technology for providing short and mediumterm electricity [4]. Also, over the past decade, the cost of producing PV cells has dropped, making electricity costs closer to the costs of conventional fuels. This development requires a detailed evaluation of PV performance over the life span to identify potential degradation phenomena [5], [6]. Examples of degradation phenomena that occur in operating PV systems are browning encapsulants, delamination and bubble formation in encapsulants, back sheet polymer cracks, front surface fouling, blackening at the bottom of the module, junction box connection, corrosion, busbar oxidation, and discoloration, crossing degradation isolation junction cables, and glass damage [7].

Over the past few years, snail trail has increasingly occurred in PV systems in the months after installation. This effect appears on the front or edge of the solar cell [8], such as small narrow dark lines and discoloration on the cell surface. In previous studies, the correlations between changes in the color of the snail trail in cells and cell micro crack have been found. Meyer et al. [9] conducted chemical tests, investigated infrared Fourier transforms, and measurements of X-ray photoelectron spectroscopy on PV modules for the analysis of snail trace defects. The snail trail was correlated with chemical reactions that occur between silver finger tissue and air humidity. 
Photovoltaic (PV) modules that are in an open environment receive different weather conditions, so many problems cause a decrease in the performance of PV modules, both temporarily and permanently. Permanent degradation occurs due to the age factor of the PV module and it will get worse when it does not well maintenance [10]. The economic life span of a PV module is calculated to be 20 years by the manufacturing industry. Lotas Off-Grid PV System capacity of $30 \mathrm{KWp}$ is located in South Central Timor Regency, built-in 2013 by the Directorate General of EBTKE of the Ministry of Energy and Mineral Resources and it was first time used in 2014. Lotas Off-Grid PV System is now 5 years old and is not functioning optimally and it is suspected that the PV module used was degraded. However, it is necessary to know with certainty the level of degradation through technical inspection and measurement of variables that affect the performance of the PV module. By doing so, the characteristics of the degraded PV module can be found. Thus the decrease in the maximum power of the PV module performance can be known with certainty to determine the maintenance and repair needed, for that reason this research needs to be conducted.

The degradation of the performance of PV modules caused by outdoor conditions is very significant. Temporary degradation factors that affect PV performance include: 1) Solar intensity. 2) Temperature. 3) Module placement position and 4) Shadow. The intensity of sunlight radiation in Kupang is very optimum in the dry season. In the mornings, afternoons and evenings the sun's radiation is very influential on the energy output of PV Modules [11]. PV module performance in the form of maximum power output varies with seasons. At the end of the summer and/or dry season, the temperature will increase and the performance of PV modules tends to increase [12].

Temperature is an important parameter of the operation of a PV system. The temperature coefficient for the open-circuit voltage ranges from $-2.3 \mathrm{mV} /{ }^{\circ} \mathrm{C}$. Therefore, the voltage coefficient of a PV module is negative and very large because it consists of 33 to 36 cells connected in series. The voltage is determined by the operating temperature of the PV and solar radiation. So that the PV output power with different specifications can be compared, the current and voltage values at certain times need to be converted to standard values using the formulas in equations (1) and (2) [13]:

$I_{2}=I_{1}+I_{s c 1}\left(\frac{G_{2}}{G_{1}}-1\right)+\alpha\left(T_{2}-T_{1}\right)$

$V_{2}=V_{1}-R_{s}\left(I_{2}-I_{1}\right)-\mathrm{k} . I_{2}\left(T_{2}-T_{1}\right)+\beta\left(T_{2}-T_{1}\right)$

From (1) and (2), Pmax $=\mathrm{I}_{2} \cdot \mathrm{V}_{2}$

Where: $I_{1}, V_{1}$ are coordinates of points on the measured characteristics; $I_{2}, V_{2}$ are coordinates of the corresponding points on the corrected characteristic; $\mathrm{G}_{1}$ is the irradiance measured with the reference device; $G_{2}$ is the irradiance at the standard or other desired irradiance; $T_{1}$ is the measured temperature of the test specimen; $\mathrm{T}_{2}$ is the standard or other desired temperature; $\mathrm{I}_{\mathrm{sc}}$ is the measured short-circuit current of the test specimen at $\mathrm{G}_{1}$ and $\mathrm{T}_{1} ; \alpha$ and $\beta$ are the current and voltage temperature coefficients of the test specimen in the standard or target irradiance for correction and within the temperature range of interest; $R_{s}$ is the internal series resistance of the test specimen; $\mathrm{k}$ is a curve correction factor.

The Fill Factor (FF) is the value of the voltage and current ratio at the maximum power state with the open circuit $\left(\mathrm{V}_{\mathrm{oc}}\right)$ voltage and short circuit current $\left(\mathrm{I}_{\mathrm{sc}}\right)$. The formulation is presented in equation (3). $\mathrm{P}_{\max }$ is one of the important electrical variables of a PV module that is often used by manufacturers to show a decrease in performance and is used to measure the 
percentage decrease of power (DoP) in the performance of degraded PV modules using equation (4).

$$
\begin{aligned}
& \mathrm{FF}=\frac{P_{\max }}{V_{\text {nn: }} I_{\text {ars }}} \\
& \mathrm{DoP}=\left(\frac{P \text { max }-P c \max }{P \max }\right) \times 100 \%
\end{aligned}
$$

Where: $\mathrm{P}_{\mathrm{nmax}}$ is new PV module and $\mathrm{P}_{\mathrm{cmax}}$ is current $\mathrm{PV}$ module.

Degradation is one of the important factors considered for calculating Lifetime Energy Production in determining the Level of Cost of Electricity in the use of PV [14], therefore, studies or research on reliability and durability PV has become an interesting topic for researchers in recent years [15]. In a study of the degradation of PV in several regions with different climatic conditions, concluded that the change in color on the surface of the PV from a base color to yellowish (yellowing) was more significantly observed in PV that existed in countries with higher environmental temperatures (higher ambient temperatures).

Degradation due to temperature was quantified further in another study in Africa [16] which found that, in addition to dust, an Organic PV (OPV) system experienced a $20 \%$ decrease in performance due to temperature measured after the system operated for 2.5 years. Dolara [17] in his research in Italy investigating the degradation of PV modules found that the PV had snail trails, micro-cracks on PV cells. As a result of these factors, PV modules that have been installed for 3 years have decreased Pmax by $10 \%$ to $30 \%$ from initial capacity. The same study was also conducted in 2016 for PV modules that had been installed for 20 years in Italy. Visually there are several degradation factors such as discoloration, junction box corrosion, delamination, front glass defects, busbar corrosion, fingers defects, cracks, dirt soiling and dark areas. As a result of these factors, there is a Pmax degradation of $22 \%$ per year. Another study [10] on PV modules with 20 years of age also found degradation factors as revealed [17].

This research is a development of previous research [11], especially in the technical inspection of the Off-Grid PV system focusing on cracks and snail trail. This research is aimed at finding the percentage of degradation caused by the snail trail and cracks as well as the decrease in power due to two types of permanent degradation in PV module. The novelty of this research is the optimization of inspection time by searching for damage per string through measurement of the output voltage of PV modules per string. The types of permanent damage that will be examined in this study include cracks and snail trail which are considered as major defects during operation. It can reduce more than $10 \%$ of the PV area and snail trails [10], [18].

\section{Method}

The first step of this research is measuring the voltage per string (Figure 1) so that the lowest voltage per string will be found. It is an indication of degradation in the PV modules which then proceed with a visual inspection. Measuring cracks and snail trail degradation is carried out for finding out the percentage of permanent damage ie the area of damage compared to the area of the PV module. After that, the module performance test is done by measuring the daily variables that affect the performance through the Real Operating 
Conditions (ROC) test include the measurement of: 1) Open-circuit voltage (Voc) 2) Shortcircuit current (Isc). 3) Solar radiation (G). 4) The temperature inside of the PV module (Figure 2).

Methods of data analysis using quantitative methods with quantification of measurement results both snail trail and crack area measurements as well as measurement results of variables that affect the performance of PV modules such as Voc, Isc, G, and T and calculating Pmax and energy production.

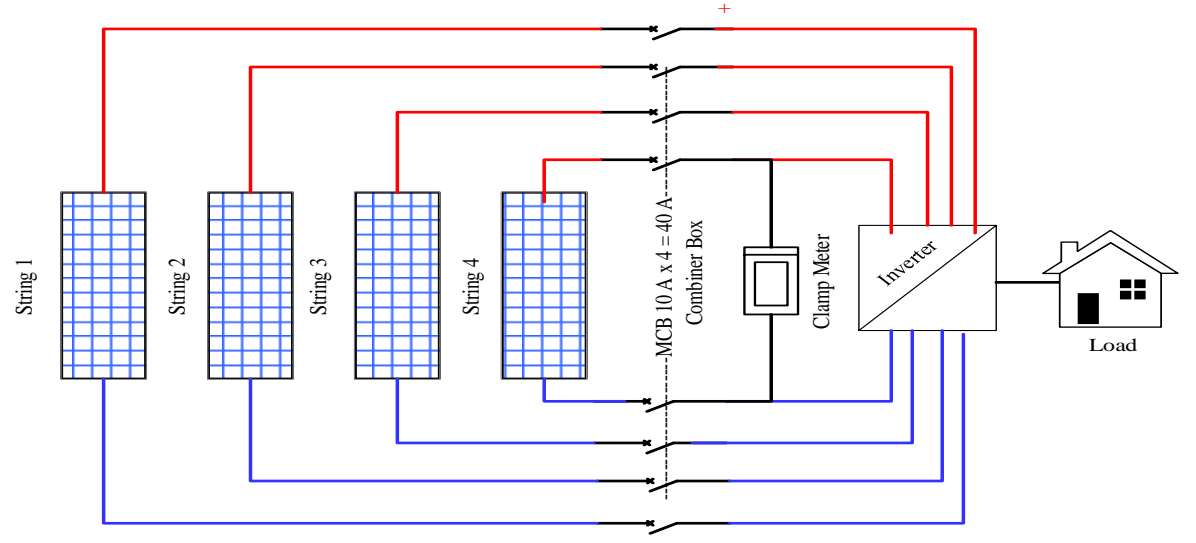

Fig.1. Schematic of the PV module voltage measurement at string connection

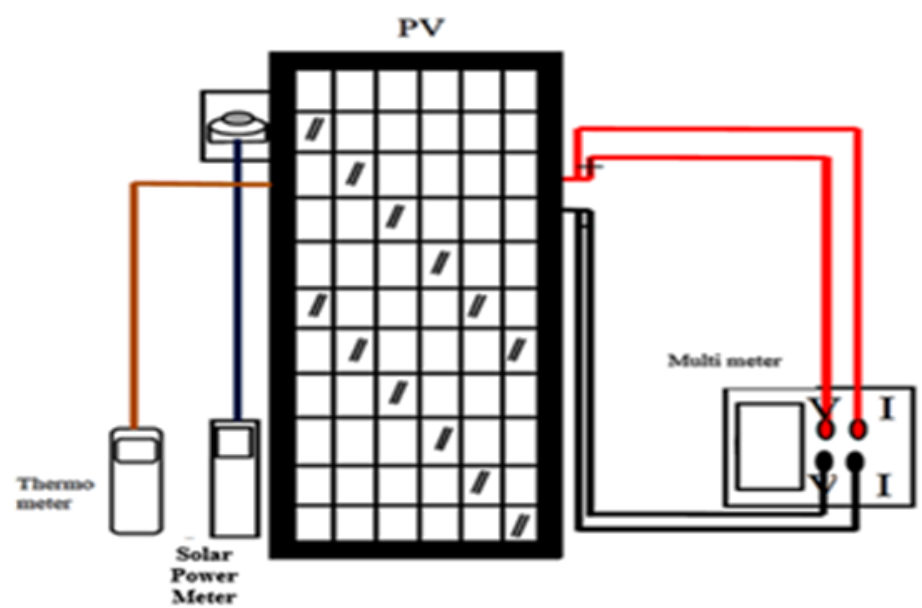

Fig.2. Schematic of the Real Operating Conditions (ROC) test 


\section{Results and Discussion}

Lotas Off-Grid PV system consists of 8 strings and each string consists of $19 \mathrm{PV}$ modules, bringing the total PV modules of 152. Each module has a capacity of $200 \mathrm{Wp}$. The lowest voltage measurement results for each string are string 1 and string 2 as shown on Table 1. For time effectiveness, visual observations are made on strings 1 and 2 . The results found in string 1 are two solar modules that are indicated by snails trail and one module that has cracks is presented in Figures 3.

Table 1. PV Module specification and string voltage measurement at

\begin{tabular}{lr|cr}
\multicolumn{4}{c}{ Lotas Off-grid PV system } \\
\hline \multirow{2}{*}{ Spesification of PV Modules and String } & String Voltage Measurement \\
\cline { 2 - 4 } & Isolar-1 & String (s) & Vs (Volt) \\
\hline Brand & SPU-180M & String 2 & 593 \\
Model Type & $200 \mathrm{~W}$ & String 3 & 598 \\
Peak Power (Pmax) & $45.9 \mathrm{~V}$ & String 4 & 736 \\
Open Circuit Voltage (Voc) & $5.5 \mathrm{~A}$ & String 5 & 681 \\
Sort Circuit Current (Isc) & $38.7 \mathrm{~V}$ & String 6 & 609 \\
Peak Voltage (Vmp) & $5.17 \mathrm{~A}$ & String 7 & 609 \\
Peak Current (Imp) & $15.21 \mathrm{Kg}$ & String 8 & 711 \\
Weight & $1000 \mathrm{~V}$ & & 667 \\
Dimension & $10 \mathrm{~A}$ & & \\
Maximum System Voltage & $1580 x 808 \times 35 \mathrm{~mm}$ & \\
Maximum Series Fuse Rating & Mono-Si & & \\
Cell Technology & 19 & \\
Number of Modules per String & 8 & \\
Number of Strings & & \\
\hline
\end{tabular}

The results of observation through visual inspection show that the Percentage of Degradation (PoD) of PV Module 1 in string 1 is caused the snail trail of $84.60 \%$, PV module 2 in string 1 is also caused by snail trail of $66.01 \%$, while PV module 3 string 2 is caused the crack of $3.98 \%$. The degradation of the PV module is presented in Figures 3, while the Percentage of Degradation (PoD) of PV Module are presented in Table 2.

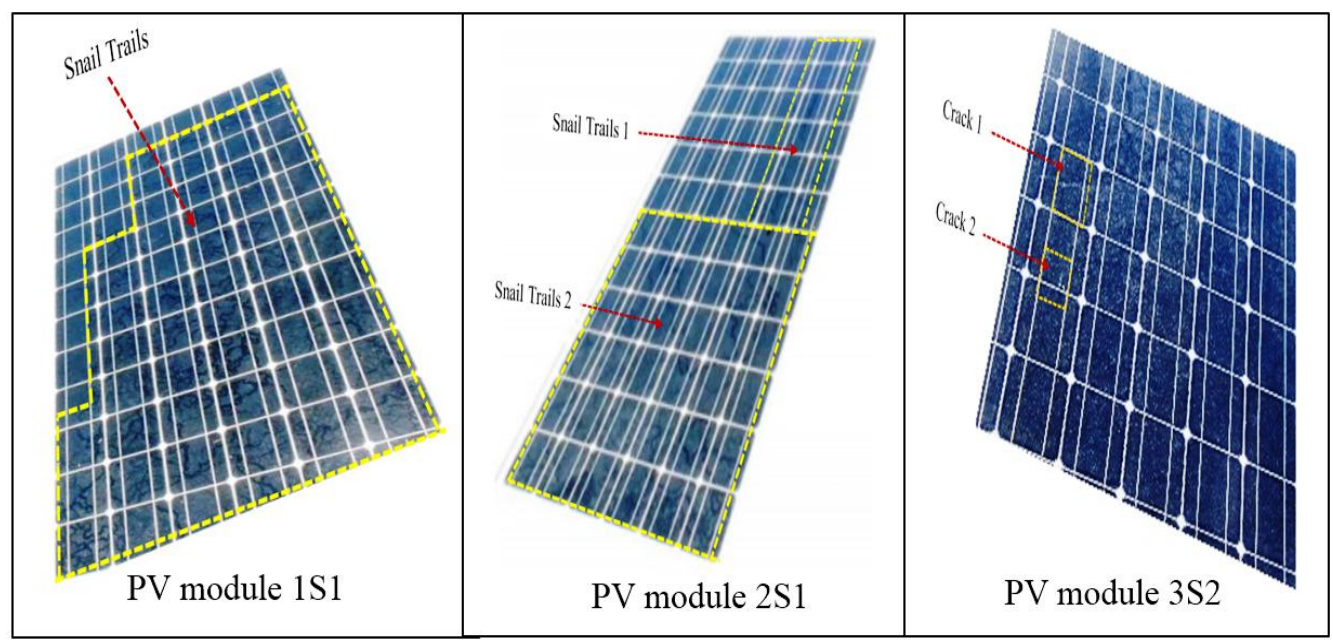

Fig. 3. The snail trail and crack degradation of the PV modules 
Table 2. Percentage of Degradation (PoD) of PV module

\begin{tabular}{cccccc}
\hline $\mathrm{Nr}$ & String & PV Module & ToD & $\mathrm{AD}\left(\mathrm{m}^{2}\right)$ & PoD $(\%)$ \\
\hline 1 & 1 & 1 & Snail Trail & 1.08000 & $84.60 \%$ \\
\hline 2 & \multirow{2}{*}{1} & \multirow{2}{*}{2} & Snail Trail 1 & 0.20025 & $15.69 \%$ \\
3 & \multirow{2}{*}{2} & \multirow{2}{*}{3} & Snail Trail 2 & 0.64240 & $50.32 \%$ \\
\hline 4 & \multirow{2}{*}{2} & Crack 1 & 0.02400 & $1.88 \%$ \\
5 & \multirow{2}{*}{} & & Crack 2 & 0.02684 & $2.10 \%$ \\
\hline
\end{tabular}

Where: AD: Area Degradation of PV Module; AoM: Area of PV Modules 1.27664 m² ToD: Type of Degradation; PoD: Percentage of Degradation

The ROC test results of PV module (200 Wp) on August 14, 2019, for 6 hours showed that the new PV module (Pmax) had the maximum power of 189.31 Watt. Meanwhile the old PV module, for maximum power of PV module after degradation by snail trails in PV module 1 in string 1 (Pmax1) of 105.25 Watt and PV module 2 on string 1 (Pmax2) was140.52 Watt. The maximum power of the PV module after degradation by a crack in PV module 3 in string 2 (Pmax3) was 158.85 Watt. Maximum power comparison curve before and after the snail trail and crack degradation through the ROC test are presented in Figure 4 and I-V curves of PV module before and after snail trail and crack degradation are presented in Figure 5.

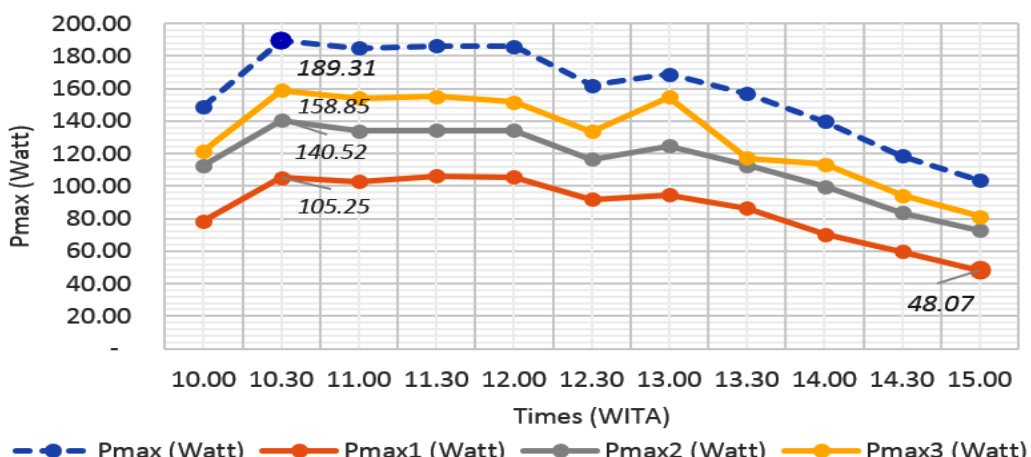

Fig. 4. Pmax curves before and after snail trail and crack degradation

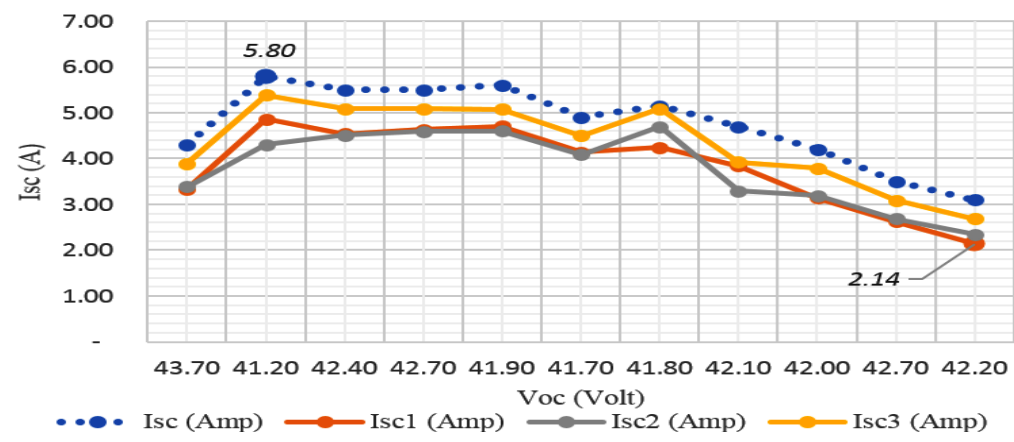

Fig. 5. I-V curves of PV modules before and after snail trail and crack degradation 
The average energy decrease after degradation by snail trails on PV module 1 in string 1 (DoE1) is $46 \%$ and the average energy decrease after degradation by snail trails on PV module 2 in string 1 (DoE2) was $28 \%$, while decrease of energy average after degradation by crack on PV module 3 in string 2 (DoE3) was 18\%. Impact of snail trail and crack to energy decrease PV modules presented on Table 3 .

Tabel 3. Impact of snail trail and crack to energy decrease PV modules

\begin{tabular}{rrrrrrrr}
\hline $\begin{array}{c}\text { Time } \\
\text { WITA }\end{array}$ & $\begin{array}{r}\text { Emax } \\
\text { (Wh) }\end{array}$ & $\begin{array}{c}\text { Emax1 } \\
\text { (Wh) }\end{array}$ & $\begin{array}{c}\text { Emax2 } \\
\text { (Wh) }\end{array}$ & $\begin{array}{c}\text { Emax3 } \\
\text { (Wh) }\end{array}$ & $\begin{array}{c}\text { DoE1 (\%) } \\
(\%)\end{array}$ & $\begin{array}{c}\text { DoE2 (\%) } \\
(\%)\end{array}$ & $\begin{array}{c}\text { DoE3 (\%) } \\
(\%)\end{array}$ \\
\hline 10.00 & 893 & 471 & 676 & 730 & $47 \%$ & $24 \%$ & $18 \%$ \\
10.30 & 1.136 & 632 & 843 & 953 & $44 \%$ & $26 \%$ & $16 \%$ \\
11.00 & 1.108 & 617 & 803 & 924 & $44 \%$ & $28 \%$ & $17 \%$ \\
11.30 & 1.116 & 637 & 806 & 932 & $43 \%$ & $28 \%$ & $17 \%$ \\
12.00 & 1.115 & 633 & 805 & 910 & $43 \%$ & $28 \%$ & $18 \%$ \\
12.30 & 971 & 551 & 699 & 802 & $43 \%$ & $28 \%$ & $17 \%$ \\
13.00 & 1.013 & 568 & 749 & 928 & $44 \%$ & $26 \%$ & $8 \%$ \\
13.30 & 941 & 518 & 675 & 702 & $45 \%$ & $28 \%$ & $25 \%$ \\
14.00 & 839 & 422 & 599 & 681 & $50 \%$ & $29 \%$ & $19 \%$ \\
14.30 & 710 & 357 & 502 & 565 & $50 \%$ & $29 \%$ & $20 \%$ \\
15.00 & 622 & 288 & 436 & 488 & $54 \%$ & $30 \%$ & $21 \%$ \\
\hline Average & 951 & 518 & 690 & 783 & $46 \%$ & $28 \%$ & $18 \%$ \\
\hline
\end{tabular}

\section{Conclusion}

Permanent degradation caused by snail trails on the PV modules area (200 Wp) of 1.08 $\mathrm{m}^{2}(84.69 \%)$ will decrease the energy of $434 \mathrm{Wh}(46 \%)$, while permanent degradation caused by cracks in the PV modules area on $0.051 \mathrm{~m}^{2}(3.98 \%)$ will decrease the energy of $168 \mathrm{Wh}$ (18\%). Permanent degradation caused by the snail trails at PV modules (200 Wp) will experience a maximum power decrease of $67 \mathrm{Watt} / \mathrm{m}^{2}$, while permanent degradation caused by crack will experience a power decrease of $551 \mathrm{Watt} / \mathrm{m}^{2}$.

\section{Acknowledgements}

The authors would like to thank Politeknik Negeri Kupang for financial support through the routine research program. Research Implementation Agreement Letter No. 78/PL23/ PPK.PNBP/PL/2019

\section{References}

[1] [UURI 16] Undang Undang Republik Indonesia Nomor 16.: Pengesahan Paris Agreement to the United Nation Faramework Convention on Climate Changes (Persetujuan Paris Atas Konvensi Kerangka Kerja Perserikatan Bangsa Bangsa Mengenai Perubahan Iklim. Jakarta (ID): Kementerian Hukum dan Hak Asasi Manusia Republik Indonesia. pp. 1-71 (2016)

[2] Sinaga, R. Prastowo, Simangunsong, B.C.H. Leabman, A. Tambunan, A.H.: Analysis of barriers in supplying electricity using interpretative structural modeling. Energy Strategy Reviews. Vol. 25, pp.11-17 (2019) 
[3] Sinaga, R. Prastowo, Simangunsong, B.C.H. Tambunan A.H.: Analisis alternatif solusi penyediaan sumber energi listrik studi kasus: Kabupaten Kupang. JTEP. Vol 5(3), pp. 283-290. (2017)

[4] IEA. Trends 2017 in Photovoltaic Applications. Available on http://ieapvps.org/fileadmin/dam/public/report/statistics/IEAPVPS Trends_2017 in Photovoltaic_Applications.pdf. (2017)

[5] Munoz, M. A. Garci, A, G.N. Vela, N. Chenlo, F.: Early degradation of silicon PV modules and guaranty conditions. Sol. Energy. Vol. 85, pp. 2264-2274, (2011)

[6] Sinaga R. Rekayasa Sistem Pengelolaan Sumber Energi Listrik. [Disertasi]. Institut Pertanian Bogor (2017)

[7] Djordjevic, S. Parlevliet, D. Jennings P.: Detectable faults on recently installed solar modules in Western Australia. Renewable Energy. Vol. 67, pp. 215-221 (2014).

[8] Meyer, S. Richter, S. Timmel, S. Glaser, M. Warner, M. Swatek, S. Hagendorf, and C.: Snail trails: Root cause analysis and test procedures. Energy Procedia. Vol. 38, pp. 498-505 (2013).

[9] Meyer, S. Timmel, S. Richter, S. Warner, M. Glaser, M. Swatek, S. Braun, U. Hagendorf, C.: Silver nanoparticles cause snail trails in photovoltaic modules. Solar Energy Material \& Solar Cells. Vol. 121, pp. 171-175 (2014)

[10] Sinclair K, Sinclair M.: Silicon Solar Module Visual Inspection Guide Catalogue of Defects to be used as a Screening Tool. Zayed Energy and Ecology Centre. Nkhata Bay District, Northern Region, Malawi (2016)

[11] Sinaga, R.: Pengaruh parameter lingkungan dan penempatan posisi modul terhadap luaran energi PLTS menggunakan solar cell $50 \mathrm{Wp}, 12$ Volt. Jurnal Studia Teknologia. SAINTEK. Vol 4(2), pp. 178-187. (2011)

[12] Tanesab, J. Parlevliet, D. Whale, J. Urmee, T.: Dust effect and its economic analysis on PV modules deployed in a temperate climate zone. Energy Procedia Vol 100, pp. 65-68 (2016)

[13] IEC. Standard-60891.: Photovoltaic Devices-Procedures for temperature and irradiance corrections to measured I-V characteristics. International Electrotechnical Commission. Geneva (2009)

[14] Tanesab, J. Parlevliet, D. Whale, J. Urmee, T. Pryor T.: The contribution of dust to performance degradation of PV modules in a temperate climate zone. School of Engineering and Information Technology, Murdoch University, Murdoch (2015)

[15] Palmblad, L. Martinsson, C. Hedstro, J. Andersson, M.: Longterm performance of PV modules-results from Swedish case studies. 4AV.3.26. Tersedia pada: http://www.aforsk.se/sites/default/files/07-156 poster.pdf. (2009)

[16] Emmott, C.J. Moia, D. Sandwell, P. Ekins, D.N. Hosel, M. Lukoschek, L. In-situ, longterm operational stability of organic photovoltaics for off-grid applications in Africa. Solar Energy Matererials \& Solar Cells. Vol 149, pp. 284-93 (2016)

[17] Dolara, A. Lazaroiu, G.C. Leva, S. Manzolini, G. Votta, L.: Snail trails and cellmicrocrack impact on PV module maximum power and energy production. IEEE Journal of Photovoltaic. Vol 6, pp. 1269-77. (2014)

[18] IEC Standard-61215. Crystalline Silicon Terrestrial Photovoltaic (PV) Modules-Design Qualifications and Type Approval. ${ }^{2}$ nd Edition. International Electrotechnical Commission. Geneva (2005). 